\title{
PERKAWINAN BEDA AGAMA DAN DAMPAKNYA TERHADAP PENDIDIKAN ANAK DI DESA WONOREJO KABUPATEN SITUBONDO
}

\author{
Muhaiminah Darajat \\ Institut Agama Islam (IAI) Syarifuddin Lumajang \\ darajatmubaiminab@gmail.com
}

\begin{abstract}
Abstrak:
Manusia adalah makluk social yang tidak mungkin bisa hidup tanpa bantuan orang lain. Karena itu, ia hidup bermasyarakat dan mengembangkan kebudayaan serta peradaban untuku kepentingan bersama. Maka pernikahan merupakan jalan dalam bersosialisasi dengan manusia lainnya. Akan tetapi jika pernikahan dihadapkan pada masalah perbedaan terutama perbedaan agama maka hal ini menjadi rumit untuk menjalankan roda kehidupan kedepan. Sebab, jika sudah memiliki anak maka hal ini dapat menimbulkan kegoncangan pada diri anak. Ia akan ragu untuk memilih antara agama ayah atau ibunya. Islam sangat jelas sekali dalam mengatur hal ini. Penelitian kualitatif deskriptif ini, bermaksud untuk mengungkap hasil dari pada pernikahan beda agama tersebut, yaitu dampak Pernikahan antar agama bagi kelangsungan pendidikan anak desa Wonorejo Kabupaten Situbondo. Dari studi penelitian yang ada terungkap bahwa Pernikahan antar agama bagaimanapun tetap merugikan, terlebih bila dipandang dari sudut pedagogis, sebab secara tidak langsung berarti sudah mempersiapkan lingkungan yang kurang baik bagi kedua belah pihak (pasangan dan keluarganya masing-masing) serta bagi kelangsungan pendidikan anakanaknya.
\end{abstract}

Kata Kunci: Perkawinan beda agama, Pendidikan Anak

\begin{abstract}
:
Social creatures, that's humans who cannot possibly live without the help of others. Therefore, he lives in society and develops culture and civilization for the common good. So marriage is a way of socializing with other humans. However, if marriage is faced with the problem of differences, especially religious differences, it becomes complicated to run the wheel of life in the future. Because, if you already bave children, this can cause shock in the child. He will hesitate to choose between the religion of his father or mother. Islam is very clear in regulating this. This descriptive qualitative research, intends to reveal the results of the interfaith marriage, namely the impact of interfaith marriage for the continuity of education for the children of Wonorejo village, Situbondo City. From existing research studies, it is revealed that interfaith marriages are still detrimental, especially when viewed from a pedagogical point of view, because it indirectly means that they have prepared an unfavorable environment for both parties (spouse and their respective families) as well as for the continuity of children's education. his son.
\end{abstract}

Keywords: Interfaith marriage, Children's Education

\section{PENDAHULUAN}

Islam Memang mengajurkan kepada setiap manusia untuk melaksanakan (perkawinan), mencari pasangan hidup dan memperbanyak keturunan. perkawinan merupakan ikatan cinta 
antara seorang laki-laki dengan seorang wanita untuk membentuk rumah tangga yang bahagia, kebahagiaan yang dipenuhi dengan kasih sayang dan didasari oleh nilai-nilai ajaran Islam.

Indonesia sendiri memiliki lima agama yang diakui sehingga menimbulkan adanya hubungan sosial antar individu beda agama dan salah satunya merupakan konsep perkawinan beda agama. Dalam pandangan masyarakat umum, praktik perkawinan beda agama merupakan suatu hal yang masih dianggap tabu untuk dilakukan, tanpa melihat aspek positif yang dapat ditimbulkan dengan adanya perkawinan beda agama. ${ }^{1}$

Masalah pernikahan beda agama juga berlajut ketika penentuan pendidikan anak, meskipun tidak mempermasahkan agama pasangannya, namun ada keyakinan dalam diri suami atau istri bahwa agamanyalah yang paling benar. keyakinan tersebut juga ditanamkan untuk masing-masing agama. agama mereka sesuai dengan agama yang dipeluk orang tuanya. suatu saat akan tampak perbedaannya dalam hal dominasi apakah pendidikan keagamaan Islam atau pendidikan keagamaan lain. ${ }^{2}$

Dengan demikian orang tua sebagai peran utama wajib bertanggung jawab atas pendidikan dan pemeliharaan bagi anaknya, sekaligus sebagai pengendali utama dalam pendidikan keluarga. Fungsi dan peran kedua orang tua sangat besar terhadap anak dan telah diakui dalam pendidikan menurut Islam, terutama bagi kedua orang tua yang beda agama. Semua hal ini bergantung pada kemauan orang tua, maka segala pengetahuan dan penghayatan serta kesdaran mengenai seluk beluk keluarga dan hubungannya dengan pendidikan anak. ${ }^{3}$

Praktik perkawinan beda agama juga terjadi di Desa Wonorejo Kabupaten Situbondo, Posisi Desa Wonorejo terletak di Kecamatan Banyuputih, Kabupaten Situbondo, Provinsi Jawa Timur. Desa ini memiliki luas 414.019 (empat ratus empat belas ribu sembilan belas) Hektar, yang terdiri dari 5 (lima) Dusun, yaitu: Dusun Randuagung, Dusun Kendal, Dusun Jelun, dan Dusun Pandean.

Sebagian besar masyarakat Desa Wonorejo ini memeluk agama Islam, dan sebagian lagi memeluk agama Kristen Protestan, Katolik serta Hindu. Kerukunan di desa ini terlihat di beberapa lokasi yang terdapat bangunan tempat ibadah umat Islam, yakni masjid yang berada di tengahtengah masyarakat beragama Kristen, Katolik dan Hindu. Selain itu, ada pula beberapa tempat ibadah gereja bagi umat Kristen dan Katolik yang lokasinya juga berada di lingkungan umat Islam.

\footnotetext{
1 Ana Lela F. CH Dkk Fikih Perkawinan Beda Agama Sebagai Upaya Harmonisasi Agama: Studi Perkawinan Beda Agama Di Jember Fikrah: Jurnal Ilmu Aqidah dan Studi Keagamaan Volume 4 Nomor 1, 2016. 199

${ }^{2}$ Nurhasanah, Implikasi larangan menikah beda agama terhadap pendidikan anak dalam keluarga 2017.21

${ }^{3}$ Kamrani Buseri, Pendidikan Keluarga dalam Islam, Yogyakarta: Andi Offset,1990
} 
Bahkan, ada juga beberapa tempat peribadatan Islam dan Kristen sengaja dibangun dengan jarak yang berdekatan. ${ }^{4}$

Namun, Fenomena semacam ini yang masih terjadi pada sebagian keluarga beda agama di desa Wonorejo kabupaten situbondo, hal ini karena ada beberapa persoalan yang menyangkut dalam status hubungan suami isteri dan status hukumnya kepada anak yang apabila memiliki keturunan. Akibatnya mulai timbul pada suatu permasalahan, dalam aspek psikologi pasangan keluarga beda agama ini menyimpan masalah terus menerus yang bisa merusak kebahagiaan maupun keharmonisan rumah tangga

kajian tentang pengelolaan dana haji sudah banyak dikaji oleh beberapa ahli. Beberapa tulisan yang dapat dijadikan sebagai kajian awal adalah Ahmadi Hasanuddin dkk tentang pernikahan beda agama ditinjau dari perspektif islam, ${ }^{5}$ Kaharuddin tentang pernikahan beda agama dan dampak terhadap pendidikan agama anak. tulisan dari Nurhasanah ${ }^{6}$ tentang implikasi larangan menikah beda agama terhadap pendidikan anak dalam keluarga dan Tati fujiyatin ${ }^{7}$ tentangdampak pernikahan beda agama tephadap pendidikan agama anak. dan tulisan lain yang juga dapat dijadikan rujukan adalah karya Ana lela $\mathrm{dkk}^{8}$ terkait dengan fikih perkawinan beda agama sebagai upaya harmonisasi agama: studi perkawinan bedaagama di jember. Berdasarkan tulisan tersebut, pembahasan tentang pernikahan beda agama belum dikaji secara komprehensif. apalagi setiap keluar akan mengalami permasalahan keluarga khusunya keluarga beda agama dalam menjadikan pendidikan anak yang baik dimasa depa. Oleh karena itu, tulisan ini berupaya untuk mengetahui Dampak Pernikahan Antar Agama Terhadap Pendidikan Moral Anak, Pendidikan Keimanan Anak dan Pendidikan Sosial Pada Anak.

\section{KAJIAN TEORI}

\section{Pengertian Pernikahan Antar Agama}

Pernikahan merupakan hubungan permanen antara laki-laki dan perempuan yang diakui syah oleh masyrakat atas dasar peraturan yang berlaku. ${ }^{9}$ Sedangkan keluarga merupakan kelompok terorganisir yang anggotanya menempati seperangkat setimbal baik definitf serta di-

\footnotetext{
${ }^{4}$ Sumarto Adi, kepala Desa Wonorejo, wawancara di kantor desa pada 06 Januari 2020.

${ }^{5}$ Ahmadi hasanuddin dardiri dkk pernikahan beda agama ditinjau dari perspektif islam dan ham khazanah, vol. 6 no.1 juni 2013

${ }^{6}$ Nurhasanah, implikasi larangan menikah beda agama terhadap pendidikan anak dalam keluarga, Undergraduate thesis, UIN Raden Intan Lampung. 2017

7 Tati Fujiyatin 2007 Dampak Pernikahan Beda Agama Tephadap Pendidikan Agama Anak (Studi Kasus Di Perumahan Jati Sawit Gamping Sleman Yogyakarta). Skripsi thesis, UIN SUNAN KALIJAGA YOGYAKARTA

${ }^{8}$ Ana lela f. Chdkk fikih perkawinan beda agama sebagai upaya harmonisasi agama: studi perkawinan bedaagama di jemberfikrah: jurnal ilmu aqidah dan studi keagamaan volume 4 nomor 1, 2016. 199

9 Parsudi Suparlan, Imu Sosial Dasar I, Jakarta: Korkosium antar Bidang Dikbud, 1982. 171
} 
dorong oleh perasaan dan sikap timbale balik. ${ }^{10}$ Karena keluarga merupakan kelompok terorganisir, maka didalamnya terdapat struktur, fungsi dan tujuan.

Pernikahan bukan ikatan lahir semata, akan tetapi merupakan ikatan lahir batin dengan tujuan yang teramat mulia yakni membentuk keluarga sejahtera dan rumah tangga bahagia menurut tuntunan ajaran Islam.

Firman Allah dalam al Qur'an Surat ar Ruum: 21:

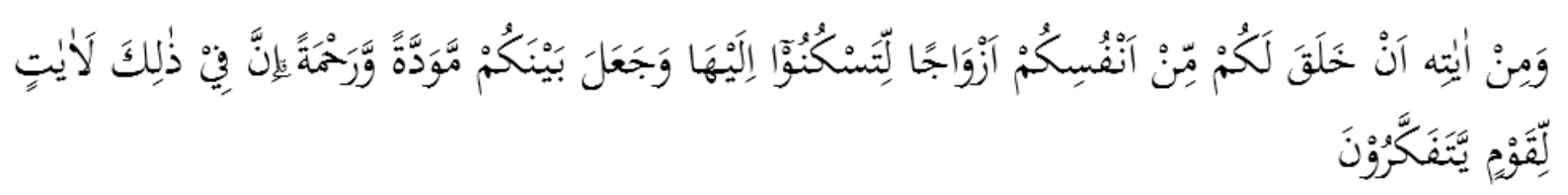

"Dan di antara tanda-tanda kekuasaan-Nya ialah Dia menciptakan untukmu isteri-isteri dari jenismu sendiri, supaya kamu cenderung dan merasa tenteram kepadanya, dan dijadikan-Nya diantaramu rasa kasib dan sayang. Sesunggubnya pada yang demikian itu benar-benar terdapat tanda-tanda bagi kaum yang berfikir."

Menurut Hasbi ${ }^{11 “}$ "Perbedaan agama ialah masing-masing orang berbeda dalam suatu agama yang berlainan dari agama orang lain." oleh Wasis ${ }^{12}$ berpendapat bahwa"Pernikahan antar agama ialah pernikahan antara seseorng baik laki-laki maupun wanita yang berlainan agamanya satu sama lain.”

Penikahan antar agama bukan pernikahan campuran, sebagaiman dimaksud oleh pasal 57 undang-undang perkawinan, yang mengatakan: ${ }^{13}$ "yang dimaksud dengan perkawinan campuran dalam undang-undang ini ialah perkawinan antara dua orang yang di Isndonesia tunduk pada hokum yang berlainan, karena perbedaan kewarganegaraan dan salah satu pihak berkewarganegaraan Indonesia."

\section{Pengertian Musyrikah}

Kata "musyrikah" berasal dari bahasa arab yang artinya menyekutukan Allah, sedangkan kafir ialah orang yang tidak beriman kepada-Nya. Muhammad Ali as Shabuni mengatakan: ${ }^{14}$

"Dan yang dimaksud dengan musyrik disini ialah orang kafir yang tidak berpedoman kepada agama Islam, termasuk di dalamnya seperti penyembah berhala, penyembah matahri (ma-

\footnotetext{
${ }^{10}$ Davis, Kingsley, Human Society, New York: Mac-Milan Co., 1963. hal 402

${ }^{11}$ Hasbi (1971: 22), Hasby as Shiddiq, T.M Prof. Dr., al Islam, Juz II, Jakarta: Bulan Bintang, 1956. 22

12 A.Wasit Aulawi, MA, H. "Perkawinan antar Agama" dalam Nasehat Perkawinan dan Keluarga (BP4), No. 92, Jakarta: Pustaka Antara, November 1979. hal 22

13 Undang-undang RI No. 2 Tahun 1989 tentang Sistem Pendidikan Nasional dan Penjelasannya, Semarang: Bulan BIntang.

${ }^{14}$ Muhammad bin Ali bin Muhammad as Syaukani, t.n., Nailul Athor, Juz VI, Beirut Lebanon: Darul Fikr. 289 
jusi), Yahudi dan Nasrani dan orang yang murtad dari agam Islam. Maka haramlah hukumnya apabila mereka menikahi wanita muslimah."

Adapun kafir menurut ulama syfi'iyah adalah orang yang mengingkari sesuatu yang dibawa Rasul. Imam Syafi'I dan Abu Hanifah menyatakan bahwa orang-orang yang mengingkari al Qur'an adalah kafir.

Pemahaman yang kami ambil adalah pengertian yang diberikan Imam Syafii dan Hanafi diatas, karena mereka tidak membenarkan Islam yang merupakan agama penyempurna dari agama-agama terdahulu, sebagaimana firman Allah dalam surat al Ma'idah ayat 3:

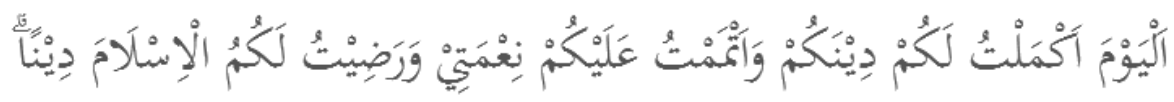

"Pada hari ini telah Kusempurnakan untuk. kamu agamamu, dan telab Ku-cukupkan kepadamu nikmat-Ku, dan telah Ku-ridhai Islam itu Jadi agama bagimu."

\section{Hukum Pernikahan Antar Agama}

Ulama berbeda pendapat dalam hal bolehnya pernikahan beda agama, ini Karen adanya perbedaan penafsiran terhadap ayat al Qur'an surat al Baqarah 221 dan al Ma’idah ayat 5:

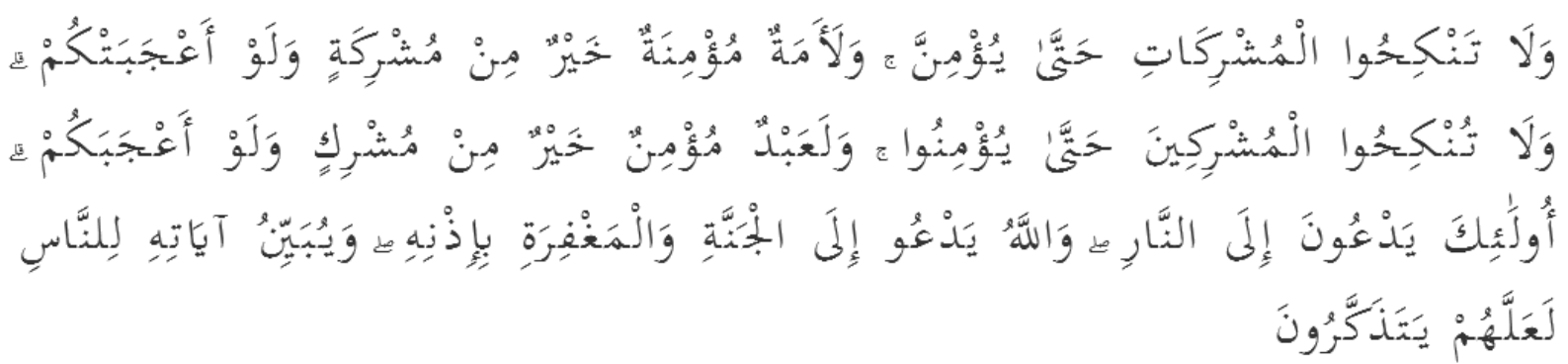

"Dan janganlah kamu menikahi wanita-wanita musyrik, sebelum mereka beriman. Sesungguhnya wanita budak yang mukmin lebih baik dari wanita musyrik, walaupun Dia menarik hatimu. dan janganlah kamu menikahkan orang-orang musyrik (dengan wanita-wanita mukmin) sebelum mereka beriman. Sesunggubnya budak yang mukmin lebih baik dari orang musyrik, walaupun Dia menarik hatimu. mereka mengajak ke neraka, sedang Allah mengajak ke surga dan ampunan dengan izin-Nya. dan Allah menerangkan ayat-ayat-Nya (perintah-perintab-Nya) kepada manusia supaya mereka mengambil pelajaran."

Ayat ini dengan tegas melarang pria muslim menikah dengan wanita musyrik sampai dia beriman, dan seorang wali dari wanita dilarang menikahkan anaknya dengan pria musyrik sampai ia beriman pula. Namun secara khusus Allah menghalalkan menikah dengan ahl kitab yang benar menjaga kehormatannya, sebagaimana dalam surat al Ma'idah ayat 5: 


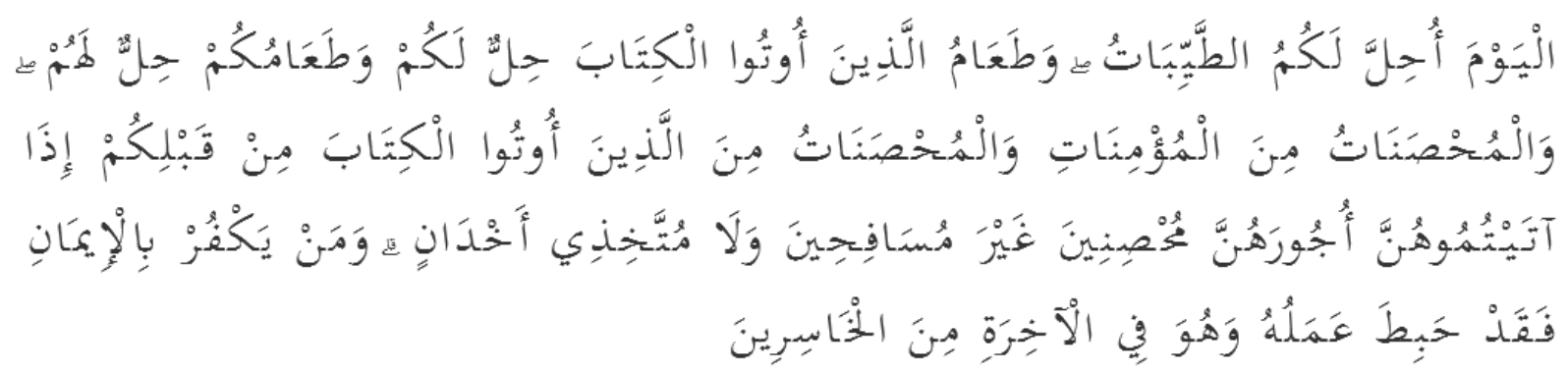

"Pada hari ini Dibalalkan bagimu yang baik-baik. makanan (sembelihan) orang-orangyang diberi Al kitab itu halal bagimu, dan makanan kamu halal (pula) bagi mereka. (dan Dibalalkan mangawini) wanita yang menjaga kehormatan [402] diantara wanita-wanita yang beriman dan wanita-wanita yang menjaga kehormatan di antara orang-orang yang diberi Al kitab sebelum kamu, bila kamu telah membayar mas kawin mereka dengan maksud menikahinya, tidak dengan maksud berzina dan tidak (pula) menjadikannya gundik-gundik. Barangsiapa yang kafir sesudah beriman (tidak menerima bukumbukum Islam) Maka hapuslah amalannya dan ia di hari kiamat Termasuk orang-orang merugi."

\section{Pandangan Ulama Terhadap Pernikahan Antar Agama}

Perkawinan Campuran karya Abdul Mutaal al Jabary:

a. Kelompok yang amat jauh dari agama Islam, peradaban dan kepercayaannya seperti penyembah berhala dan atheis. Mengawini kelompok inihukumnya ham mutlak.

b. Kelompok yang agak dekat dengan Islam seperti ahli kitab yang percaya kepada Alllah dan hari akhir. Islam memperbolehkan kawin dengan wanita kelmpok ini apabila dalam keadaan darurat untuk tujuan siyasy, sehingga tidak tergelincir dalam perbuatan ynag diharamkan Tuhan.

Pendapat golongan Syi'ah Imamiyah, Ibn Umar, sebagian pendapat Imam Syafi'i melarang dengan tegas pernikahan antar agama, kecuali setelah mereka beriman dan masuk Islam. Ini didasarkan pada dalil-dalil berikut:

Pendapat Ibnu Umar, Muhammad Ali as Shabuny, ${ }^{15}$

"Ibnu Umar ketika ditanya tentang seorang lelaki muslim yang menikabi wanita Nasrani dan Yabudi, jawabnya: "Allah SWT telah mengharamkan wanita-wanita musyrikah bagi laki-laki muslim (karena kemusyrikannya), saya tidak melibat kemusyrikan Allah yang lebih besar dariwanit yang mengatakan babwa tuhnnay Isa atau seorang hamba (Uzair) daripada menjadi hamba Allah SWT."

Dengan alasan "kemusyrikannya" dalam menolak risalah Islamiyah inilah seorang non Muslim haram dinikahi. Hal ini dipertegas lagi dalam QS. Yusuf: 106:

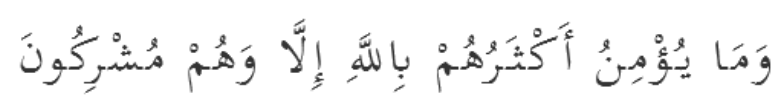

15 Muhammad bin Ali bin Muhammad as Syaukani, t.n., Nailul Athor, Juz VI, Beirut Lebanon: Darul Fikr. 287 
"Dan sebagian besar dari mereka tidak beriman kepada Allah, melainkan dalam Keadaan mempersekutukan Allab (dengan sembahan-sembahan lain)."

Golongan jumhur ulama, yakni Imam Madzhab empat berpendapat bahwa pernikahan seorang muslim dengan non muslim (ahli kitab: Yahudi dan Nasrani) adalah halal, dengan dalil sebagai berikut:

Pertama, pengalaman sejarah, setelah turunnya al Ma'idah ayat 5, banyak diantara sahbat Nabi dan Tabi'in melangsungkan pernikahan dengan seorang non muslim, sperti dai golongan sahabat; Utsman bin Affan, Thalhah bin Ubaidillah, Ibnu Abbas, Jabir dan lain-lain. Sedangkan dari longan Tabi'in: Sa'ad bin Musayyab, Sa'id bin Zubair, Hasan, Mujahid, Thawus, Ikrimah dan lain-lain.

Kedua, karena adanya pertalian (alaqah) yakni dalam hal sama-sam mengakui adanya Allah dan memilki kitabsuci yang ditrunkan Allah melalui rasul-Nya, yag menjadi pedoman sebagai sumber syariat agama yang dianutnya.

Ketiga, ayat 5 surat al Ma’idah tidak dinasakh al Baqarah 221, sbab al Ma'idah lebih akhir turunnya dari ayat 221 al Baqarah..

Keempat, keputusan MUNAS II MUI tanggal 11 s/d 17 Rajab 1400 H, bertepatan dengan tanggal 6 Mei s/d 1 Juni 1988 bertempat di Jakarta, mengeluarkan fatwa mengenai pernikahan beda agama, sebagaimana tertulis dalam buku tuntunan pernikahan bagi umat Islam Indonesia yang isinya:

a. Pernikahan wanita muslimah dengan lelaki non muslim adalah haram hukumya.

b. Seorang lelaki diharamkan menikahi wanita non muslim

\section{Pendidikan Anak Dalam Islam}

Pendidikan anak merupakan bimbingan dan pertolongan secara sadar yang diberikan oleh orang tua kepada anak sesuai dengan perkembangan jasmani dan rohaniah. Dalam pendidikan anak pernikahan beda agama sangat berpengaruh bagi perkembangannya. Segala tingkah laku dan cara bicara baik maupun buruk akan mudah ditiru oleh anak. Karenanya orang tua harus bijaksana terhadap [erkembangan anak. Jadi jelas dini pentingnya peranan orang tua untuk menanamkan pandangan hidup keagamaan terhadap anak.

Agama anak yang akan dianutnya semata-mata bergantung pada pengaruh orang tua dan lingkungan sekitarnya. Karena itu alQur'an telah menggambarkan bagaimana Luqman sebagai orang tua telah menanamkan pendidikan agama kepada naknya, sebagaimana terdapat dalam QS. Luqman: 13:

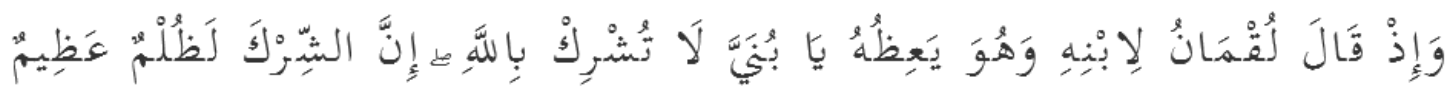


'Dan (ingatlah) ketika Luqman berkata kepada anaknya, di waktu ia memberi pelajaran kepadanya: "Hai anakku, janganlah kamu mempersekutukan Allah,sepenubnya dari pendidik (orang) Sesunggubnya mempersekutukan (Allah) adalah benar-benar kezaliman yang besar".

Sering dikatakan orang bahwa membesarkan dan mendidik anak merupkan tugas yang berat dan sulit, namun itu juga dapat menjadi menyenangkan dan sangat bermanfaat.

\section{Kewajiban Orang Tua Mendidik Anak Menurut Islam}

Anak merupakan amanat Allah yang harus dipertanggungjawabkan kehadirannya, kelahirannya itu telah dibekali dengan potensi atau kekuatan pendorong alamiah yang dapat diarahknan kepada arah yang baik maupun sebaliknya. Karenanya merupakan kewajiban orang tua sebagai pemeran utama untuk mengarahkan potensi tersebut supaya anak dapat mengembangkan dirinya kea rah keriloan Allah SWT, sebagaimana ditegaskana dala al Qur'an surat at Tahrim ayat 6:

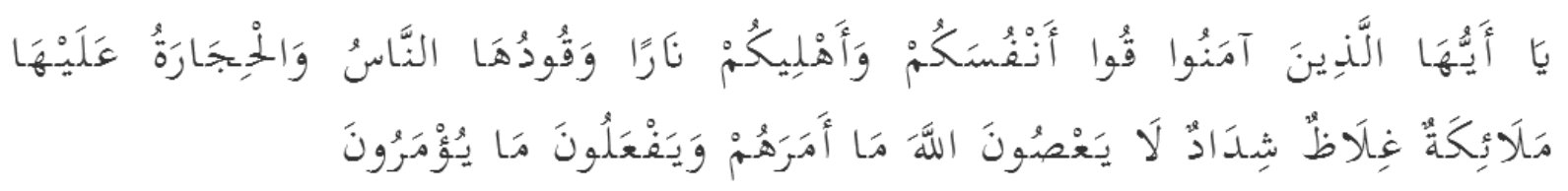

"Hai orang-orang yang beriman, peliharalah dirimu dan keluargamu dari api neraka yang bahan bakarnya adalab manusia dan batu; penjaganya malaikat-malaikat yang kasar, keras, dan tidak mendurbakai Allah terhadap apa yang diperintabkan-Nya kepada mereka dan selalu mengerjakan apa yang diperintabkan.”

Sebagai tindak lanjut dari gambaran keharusan mendidik yang tertuang dalam ayat atau hadits, maka berikut langkah-langkah penjabarannya untuk dapat dijadikan pedoman dalam hal mendididk anak:

1. Dengan cara menanamkan tauhid sejak kecil, Menanamkan ajaran Tauhid sejak dini merupakan tugas utama, bila gagal dalam menanamkan aspek in, maka berarti gagal pula pendidikan pada aspek-aspek lainnya.

2. Agar berbakti kepada kedua orang tuanya, hormat, patuh dan taat terhadap kedua orang tua merupakan keharusan anak, mengingat jasanya bagi sang anak sangatlah besar sejak anak berada dalam kandungan ibunya.

3. Mengajarkan ilmu-ilmu umum, Meskipun mengajar ilmu umum itu biasanya dilaksanakan di sekolah, namun kelurga sebagai instansi penanggung jawab utama perkembangan anaknya, berkewajiban pula mengajarkan ilmu ilmu-ilmu umum, bila tidak berkesanggupan maka orang tua berkewajiban meberi motivasi terhadap anaknya serta menjalin terus hubungan timbale balik antara pihak sekolah dan keluarga guna memanatu perkembangan anak baik fisik maupun kemampuannya. 


\section{METODE PENELITIAN}

Penelitian ini menggunakan jenis penelitian kualitatif. Menurut Strauss \& Corbin dalam ${ }^{16}$ penelitian kualitatif merupakan penelitian yang temuannya tidak diperoleh melalui prosedur statistik atau bentuk hitungan lainnya. Bertujuan untuk memahami obyek yang diteliti secara mendalam Bertujuan untuk mengembangkan konsep sensitivitas pada masalah yang dihadapi. ${ }^{17}$

Penelitian ini mendeskripsikan tentang pemecahan persoalan yang diteliti dengan memaparkan data tentang Pernikahan Beda Agama dan Dampaknya terhadap pendidikan Anak sehingga objek permasalahan dapat terpapar dengan jelas. Penelitian ini menggunakan teknik wawancara secara langsung dan observasi sebagai teknik pengumpulan data. Adapun lokasi penelitian yaitu di Desa Wonorejo Kabupaten Situbondo.

\section{PEMBAHASAN}

\section{Perkawinan Antar Pemeluk Agama Yang Berbeda}

Al-Quran juga secara tegas melarang perkawinan dengan orang musyrik seperti FirmanNya dalam surat Al-Baqarah (2): Dan janganlah kamu menikahi wanita-wanita musyrik sebelum mereka beriman. Larangan serupa juga ditujukan kepada para wali agar tidak menikahkan perempuan-perempuan yang berada dalam perwaliannya kepada laki-laki musyrik. Dan janganlah kamu menikahkan orang-orang musyrik (dengan wanita-wanita Mukmin) sebelum mereka beriman. $^{18}$

Menurut sementara ulama walaupun ada ayat yang membolehkan perkawinan pria Muslim dengan wanita Ahl Al-Kitab (penganut agama Yahudi dan Kristen), yakni surat Al-Maidah (yang menyatakan, Dan (dihalalkan pula) bagi kamu (mengawini).

Tetapi izin tersebut telah digugurkan oleh surat Al-Baqarah ayat 221 di atas. Sahabat Nabi, Abdullah Ibnu Umar, bahkan mengatakan:

"Saya tidak mengetahui kemusyrikan yang lebih besar dan kemusyrikan seseorang yang menyatakan bahwa Tubannya adaLab Isa atau salah seorang dari hamba Allah."

Pendapat ini tidak didukung oleh mayoritas sahabat Nabi dan ulama. Mereka tetap berpegang kepada teks ayat yang membolehkan perkawinan semacam itu, dan menyatakan bahwa walaupun aqidah Ketuhanan ajaran Yahudi dan Kristen tidak sepenuhnya sama dengan aqidah

\footnotetext{
16 Surayya, R. (2018). Pendekatan kualitatif dalam penelitian kesehatan. AVERROUS: Jurnal Kedokteran Dan Kesehatan Malikussaleh, 1(2), 75-83.

17 Gunawan, I. (2013). Metode Penelitian Kualitatif. Jakarta: Bumi Aksara, 143.

18 QS, Al-Baqarah 221
} 
Islam, tetapi Al-Quran tidak menamai mereka yang menganut Kristen dan Yahudi sebagai orangorang musyrik. Firman Allah dalam surat A1-Bayyinah (98): 1 dijadikan salah satu alasannya.

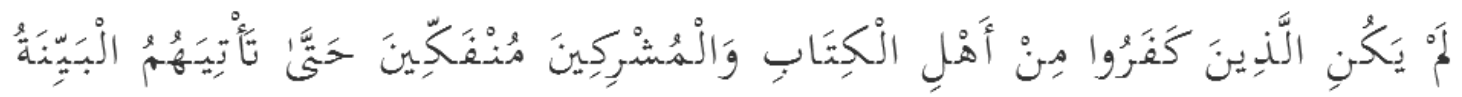

"Orang kafir yang terdiri dari Abl Al-Kitab dan Al-Musyrikin (menyatakan bahwa) mereka tidak. akan meninggalkan agamanya sebelum datang kepada mereka bukti yang nyata” (QS. Al-Bayyinah [98]: 1).

Ayat ini menjadikan orang kafir terbagi dalam dua kelompok berbeda, yaitu Ahl Al-Kitab dan Al-Musyrikin. Perbedaan ini dipahami dari kata "wa" yang diterjemahkan "dan", yang oleh pakar bahasa dinyatakan sebagai mengandung makna "menghimpun dua hal yang berbeda."

Larangan mengawinkan perempuan Muslimah dengan pria non-Muslim termasuk pria Ahl Al-Kitab diisyaratkan oleh Al-Quran. Isyarat ini dipahami dari redaksi surat Al-Baqarah (2): 221 di atas, yang hanya berbicara tentang bolehnya perkawinan pria Muslim dengan wanita Ahl Al-Kitab, dan sedikit pun tidak menyinggung sebaliknya. Sehingga, seandainya pernikahan semacam itu dibolehkan, maka pasti ayat tersebut akan menegaskannya. ${ }^{19}$

Larangan perkawinan antar pemeluk agama yang berbeda itu agaknya dilatarbelakangi oleh harapan akan lahirnya sakinah dalam keluarga. Perkawinan baru akan langgeng dan tenteram jika terdapat kesesuaian pandangan hidup antar suami dan istri, karena jangankan perbedaan agama, perbedaan budaya, atau bahkan perbedaan tingkat pendidikan antara suami dan istri pun tidak jarang mengakibatkan kegagalan perkawinan. Memang ayat itu membolehkan perkawinan antara pria Muslim dan perempuan Utul Kitab (Ahl Al-Kitab), ${ }^{20}$ tetapi kebolehan itu bukan saja sebagai jalan keluar dari kebutuhan mendesak ketika itu, tetapi juga karena seorang Muslim mengakui bahwa Isa a.s. adalah Nabi Allah pembawa ajaran agama. ${ }^{21}$ Sehingga, pria yang biasanya lebih kuat dari wanita jika beragama Islam dapat mentoleransi dan mempersilakan Ahl Al-Kitab menganut dan melaksanakan syariat agamanya, Bagi kamu agamamu dan bagiku agamaku. ${ }^{22}$

Ini berbeda dengan Ahl Al-Kitab yang tidak mengakui Muhammad SAW. sebagai nabi. Di sisi lain harus pula dicatat bahwa para ulama yang membolehkan perkawinan pria Muslim dengan Ahl Al-Kitab, juga berbeda pendapat tentang makna Ahl Al-Kitab dalam ayat ini, serta keberlakuan hukum tersebut hingga kini. Walaupun penulis cenderung berpendapat bahwa ayat tersebut tetap berlaku hingga kini terhadap semua penganut ajaran Yahudi dan Kristen, namun

\footnotetext{
19 Zainuddin, Anak Dalam Lingkungan Menurut Pandangan Islam, Semarang: Utama Pria, 1994 hal 96

${ }^{20}$ Muchtar Nasir, K.H, et. al., Pedoman Pegawai Pencatat Nikah (PPN), Proyek Pembinaan Sarana Keagamaan Islam, Jakarta: 1982.

${ }^{21}$ Kamrani Buseri, Pendidikan Keluarga dalam Islam, Yogyakarta: Andi Offset,1990.

22 QS Al-Kafirun: 6.
} 
yang perlu diingat bahwa Ahl Al-Kitab yang boleh dikawini itu, adalah yang diungkapkan dalam redaksi ayat tersebut sebagai "wal muhshanat minal ladzina utul kitab". Kata al-muhshnnat di sini berarti wanita-wanita terhormat yang selalu menjaga kesuciannya, dan yang sangat menghormati dan mengagungkan Kitab Suci. Makna terakhir ini dipahami dari penggunaan kata utuw yang selalu digunakan Al-Quran untuk menjelaskan pemberian yang agung lagi terhormat. itu Sebabnya ayat tersebut tidak menggunakan istilah Ahl Al-Kitab, sebagaimana dalam ayat-ayat lain, ketika berbicara tentang penganut ajaran Yahudi dan Kristen. Pada akhirnya betapapun berbeda pendapat ulama tentang boleh tidaknya perkawinan Muslim dengan wanita-wanita Ahl Al-Kitab, namun seperti tulis Mahmud Syaltut dalam kumpulan fatwanya. ${ }^{23}$

Pendapat para ulama yang membolehkan itu berdasarkan kaidah syar'iyah yang normal, yaitu bahwa suami memiliki tanggung jawab kepemimpinan terhadap istri, serta memiliki wewenang dan fungsi pengarahan terhadap keluarga dan anak-anak. Adalah kewajiban seorang suami Muslim --berdasarkan hak kepemimpinan yang disandangnya untuk mendidik anak-anak dan keluarganya dengan akhlak Islam. Laki-laki diperbolehkan mengawini non-Muslimah yang Ahl Al-Kitab, agar perkawinan itu membawa misi kasih sayang dan harmonisme, sehingga terkikis dari hati istrinya rasa tidak senangnya terhadap Islam. Dan dengan perlakuan suaminya yang baik yang berbeda agama dengannya itu, sang istri dapat lebih mengenal keindahan dan keutamaan agama Islam secara amaliah praktis, sehingga ia mendapatkan dari dampak perlakuan baik itu ketenangan, kebebasan beragama, serta hak-haknya yang sempurna, lagi tidak kurang sebaik istri.

Selanjutnya Mahmud Syaltut menegaskan bahwa kalau apa yang dilukiskan di atas tidak terpenuhi sebagaimana sering terjadi pada masa kini maka ulama sepakat untuk tidak membenarkan perkawinan itu, termasuk oleh mereka yang tadinya membolehkan.

\section{Dampak Pendidikan Anak Dari Sebab Pernikahan Beda Agama}

Pernikahan antar agama berdampak negative bagi kedua belah pihak, terlebih lagi bagi kelangsungan pendidikan anak-anak yang diperoleh dari hasil pernikahan tersebut. Seperti terlihat dari analisa penulis berikut ini:

1. Adanya keharusan menjaga diri dan keluarga dari siksa api neraka terkandung makna keselamatan diri pribadi sejak awal melangkah memilih pasangan dan seluruh anggota keluarga dari kemungkinan terjerumus ke jurang kesenangan dunia akhirat. Sedangkan kita sama-sama mengetahui bahwa penjagaan itu hanya bisa diwujudkan dengan menggunakan jalur pendidikan dan pengajaran, sebab bagaimana mungkin bisa menyelamatkan diri tanpa mengetahui apa dan bagaimana seharusnya menyelematkan diri? Maka pendidikan dan pengajaran yang bermu-

\footnotetext{
${ }^{23}$ Muhammad bin Ali bin Muhammad as Syaukani, t.n., Nailul Athor, Juz VI, Beirut Lebanon: Darul Fikr.
} 
ara pada satu arahlah yang dapat membawa kea rah keselamatan baik suami maupun istriserta sluruh anggota keluarga yang menjadi tanggungannya.

2. Yahudi dan Nasrnai terlebih yang tidak meiliki kitab suci, kenyataan id lapangan saat ini secara terang-terangan walaupun dalam gerak langkah serta cara dalam menata dunia ini berkeinginan menghancurkan Islam melalui berbagai cara, sisitem dan kesempatan, karenanya selaku umat Islam dituntut untuk senantiasa waspada (termasuk dalam hal menikah). Pendek kata mereka (non muslim) lah yang sebaiknya terpengaruhi kita (pasangan muslim), bikan sebaliknya. Ketidakmungkinan untuk mendapat nilai tujuan yang terkandung dalam perkawinan Islam, bila keduanya tidak mencerminkan sikap mendidik terlebih lagi pendidikan anaknya kelak senantiasa terumbang-ambing.

3. Pernikahan antar agama dapat menimbulkan tekanan psikologis bagi anak, sebab anak dituntut taat kepada orang tuanya dai suatu saat dan tidak perlu taat pada saat yang lain. Ini sebagaimana telah digambarkan dalam QS Luqman: 15, Allah berfirman:

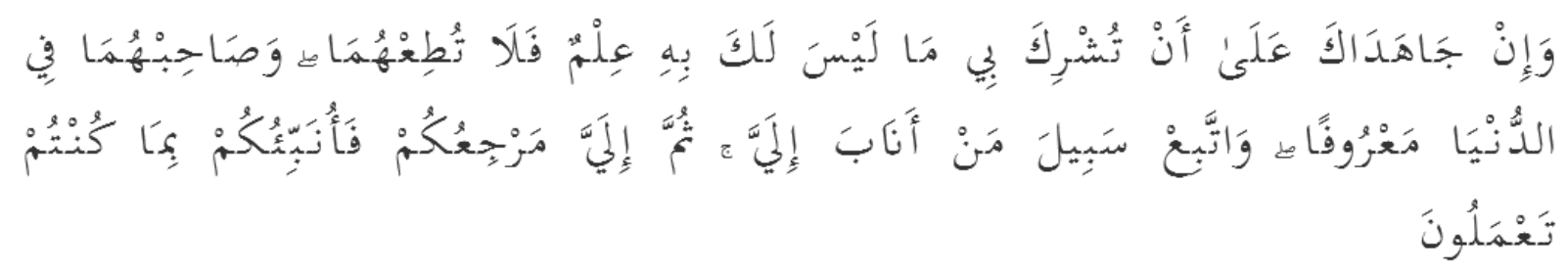

"Dan jike keduanya memaksamu untuk mempersekutukan dengan aku sesuatu yang tidak ada pengetahuanmu tentang itu, Maka janganlah kamu mengikuti keduanya, dan pergaulilah keduanya di dunia dengan baik, dan ikutilah jalan orang yang kembali kepada-Ku, kemudian hanya kepada-Kulah keembalimu, Maka Kuberitakan kepadamu apa yang telab kamu kerjakan.”

Bila perkawinan itu dilakukan karena seagama, niscaya tidak akan timbul tekanan psikologis semacam itu, sebab antar kedua belah pihak dan anak berada dalam suatu naungan aqidah, syariat dan akhlaq.

1. Pernikahan antar agama ternyata masih dipermasalahkan di kalangan ulama, karena dampak negatifnya ditimbulkna tidak hanya dirasakan oleh pelaku penikahan itu semata, namun dapat berakibat panjang terutama dalam pembentukakkn drurriyatun thayyibatan, mengingat terwujudnya hal tersebut snangat bergantung kepada penbinaan yang ditanamkannya sejak dini.

2. Jadi kita sebagai umat Islam agar senantiasa waspada dalam menghadapi gerak-gerik Yahudi dan Nasranai, yang senantiasa waspada lihai dan halus dalam menggunakan kesempatan. Dengan cara meningkatkan terus kualitas pendidikan bagi anak-anka kita agar keturunan kita dan pola kehidupannya tidak meniru pada yang mereka (Yahudi dan Nasrani) terapkan. 
3. Bila pernikahan antar agama benar-benar terjadi dan akhirnya dari pernikahan itu dikaruniai anak, maka dalam hal agama anak ituu dikuatkan kepada agama ayahnya, mengingat sebab dibolehkannya menikah dengan wanita ahli kitab itu untuk suatu tujuan dan alasan dakwah islamiyah, agar anak jangan terseret kepada agama kitabiyah.

\section{Dampak Pernikahan Antar Agama Terhadap Pendidikan Moral Anak}

Masalah moral dan agama menjadi problem besar pada masa pancaroba. Pada masa ini, anak belum mempumyai peganagan hidup yang tetap, memang mereka sedang mencari karena pada periode ini sering terjadi konversi agama, apalagi dalam keluarga yang berbeda-beda agamanya. Demikian pula dengan masalah moral, pada periode ini anak mempunyai konsep yang merupakan standard baginya. Hal ini disebabkan karena pada saat itu anak belum mempunyai pengetahuan yang matang dalam masalah moral, lebih-lebih dalam masalah orang tua yang berbeda keyakinan. ${ }^{24}$ Masalah moral mengalami kegoncangan hebat, sehingga akan banyak mengalami konflik dengan masyarakat terutama konflik masalah moral dan agama, yang kadang problem mereka meliputi masalah-masalah berikut:

1. Budi pekerti dan agama, seperti seorang anak ingin pindah agama yang baru, yang dirasa lebih baik dari agamanya terdahulu tetapi merasa berdosa berdasar agamanya yang lama hingga menimbulkan problem.

2. Adat istiadat, seperti pakaian di rumah sedemikian rupa, tetapi tuntutan pakaian di sekolah harus memakia rok atau yang lainnya yang bertentangan dengan adat setempat.

3. Pergaulan, seperti bagaimana bertindak supya diterima oleh masyarakat, bagaimana memilih teman dalam pergaulan dan sebagainya. ${ }^{25}$

Metode handal dan influitif dalam mempersiapkan dan membentuk anak dalam moral spiritual dan social. Tidak beda dengan pendidikan ibadah adalah pendidikan akhlaq. Menurut al Ghazali, akhlaq merupakan sifat atau kaeadaan dan perilaku yang tetap dan meresapkan dalam jiwa, sehingga lahirlah perbuatan-perbuatan dengan wajar tanpa memerlukan pikiran dan pertimbangan. Dari definisi ini dapat dijelaskan dua hakikat akhlaq menurut Ghazali, pertama, serbuatan itu harus konstan dan dilakukan berulang kali dalam bentuk yang sama shingga dapat menjadi kebiasaan. Kedua, perbuatan yang konstan tersebut harus tumbuh dengan mudah sebagai wujud refleksi dari jiwa tanpa pertimbangan dan pemikiran, dengan kata lin tidak ada tekanan atau paksaan dari pihak luar atau juga pengaruh dan bujukan. ${ }^{26}$

Pendidikan akhlaq merupakan pokok budi pekerti, dilakukan dengan latihan dan pembiasaan dan yang tepenting adalah keteladanan. Solusi yang diajukan para pengajar agama untuk

\footnotetext{
${ }^{24}$ Muhammad Zein, Metodologi Pengajaran Agama, Yogyakarta: 1995. hal 64

${ }^{25}$ Muhammad Zein, Metodologi Pengajaran Agama, Yogyakarta:1995. hal 65-66

${ }^{26}$ Zainuddin, Anak Dalam Lingkungan Menurut Pandangan Islam, Semarang: Utama Pria, 1994. hal 102
} 
mengatasi masalah akhlaq adalah dengan memberikan dasar-dasar keteladanan yang kuat, karena apbila pendidikan akhlaq kini hanya diberikan dengan cara memberi ceramah atau dicekoki dengan nasehat tanpa aktualisasi oleh para pendidik sendiri, bagaikan menyembuhkan penyakit hanya dengan tulisan atau mantra-mantra sehingga kemungkinan kecil berhasil.

Menurut Zakiah Darajat, pendidikan moral harus diimtensifkan an perlu dilaksanakan serentak, yaitu pada hal-hal berikut

1. Adanya hubungan antara orang tua dan anak

2. Pendidikan moral yang paling baik terdapat dalam agama atau keyakinan.

3. Pendidikan dan perlakuan orang tua terhadap anaknya hendaknya menjamin segala kebutuhan, baik fisik maupun psikis dan social.

4. Orang tua harus memperhatiikan pendidikan moral serta tingkah laku anak-anaknya.

Bila ditinjau dari psikologis maupun sosiologis, anak menempati posisi yang sangat bernilai karena ia merupakan karunia Allah. Sebagai karunia diisyaratkan oleh Islamagar jangan sirna di tengah perjalanan menuju kedewasaannya. Oleh karena itu, setiap menikmati karunia yang besar ini harus pula didasari bahwa anak juga sebagai amanat yang diberikan Allah pada setiap orang tua. $^{27}$

Hubungan anak dengan orang tuanya mempunyai pengaruh dalam perkembangan agamanya, sehingga dampaknya sang anak akan mengalami kebingungan dalam hal agamanya, anak yang merasakan adanya hubungan hangat dengan orang tuanya dan selanjutnya akan cenderung ke agama, ironisnya bagi kita, apabila yang mempunyai hubungan erat dengan anak adalah orang tu yang non muslim.

\section{Dampak Pernikahan Antar Agama Terhadap Pendidikan Keimanan Anak}

Al Ghazali mengatakan bahwa iman adalah mengucapkan dengan lidah, mengakui benarnya dengan hati dan mengamnalkan dengan anggota badan. Jelasnya bahwa pengertian ini meliputi tiga aspek, pertama, ucapan lidah atau mulut, karena lidah adalah penerjemah hati, akan tetapi bayi yang baru lahir telah mengakui adanya Allah dengan pengakuan jiwa, bukan dengan lidah. Kedua, pembenaran hati dengan cara I'tiqad dan taqlid bagi orang awam atau manusia pada umumnya. Sedangkansecara kasyaf (pengetahuan mendalam dengan membuka hijab hati) bagi orang-orang khawas (khusus). Ketiga, amal oerbuatan yang dihitung dari sebagian iman, karena ia melengkapi dan menyempurnakan iman sehingga bertambah dan berkurangnya iman seseorang adalah dari amal perbuatan. ${ }^{28}$

${ }^{27}$ Kamrani Buseri, Pendidikan Keluarga dalam Islam, Yogyakarta: Andi Offset,1990. hal 28

28 Zainuddin, Anak Dalam Lingkungan Menurut Pandangan Islam, Semarang: Utama Pria, 1994. hal 27 
Dalam menanamkan penddikan keimanan pada seorang anak, sebagaimana yang pernah dilakukan luqman yang teterara dalam QS. Luqman: 13:

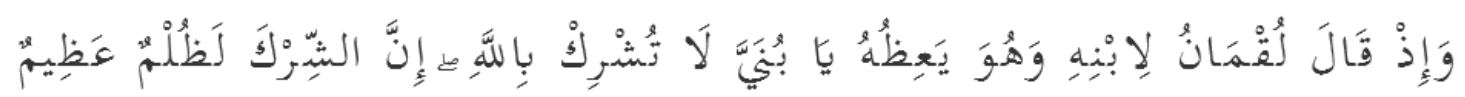

'Dan (ingatlah) ketika Luqman berkata kepada anaknya, di waktu ia memberi pelajaran kepadanya: "Hai anakku, janganlah kamu mempersekutukan Allah, Sesunggubnya mempersekutukan (Allah) adalab benar-benar kezaliman yang besar".

Dengan demikian dampak dari pernikahan beda agama akan sangat besar sekali terhadap perkembangan pendidikan anak sehingga anak mengalami kebingungan untuk menentukan keyakinannya sendiri, sehingga anak tidak percaya diri apakah harus mengikuti agama ayah atau ibunya.

\section{Dampak Pernikahan Antar Agama Pada Pendidikan Sosial Anak}

Kebutuhan sosisl merupakan salah satu kebutuhan manusia dimana ia memerlukan interaksi dengan sesamanya. Hal ini kareana manusia merupakan makhluk social yang emmpunyai pembawaan untuk hidup bermasyarakat. ${ }^{29}$

Sebelum seorang anak terjun ke dalam lingkungan yang lebih luas (masyarakat), terlebih dahulu harus dibekali dengan pendidikan social, agar mengerti tentang etika (norma). Dasar dari kebutuhan social ini tercantum dalam QS. Al Hujarat: 10:

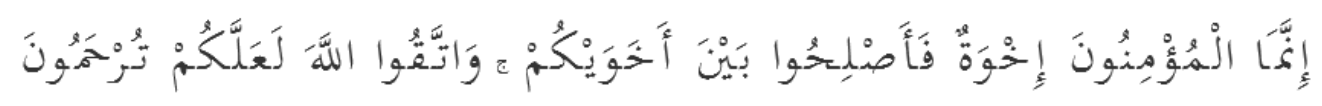

"Orang-orang beriman itu Sesunggubnya bersaudara. sebab itu damaikanlab (perbaikilab bubungan) antara kedua saudaramu itu dan takutlah terhadap Allah, supaya kamu mendapat rabmat". 30

Ayat ini menerangkan bahwa ajaran Islam begitu menekankan tentang kebutuhan social ini. secara sosiologis manusia adalah makhluk social, ia tidak dapat hidup soerang diri dan terpisah dari manusia lainnya. Manusia senantiasa hidup dalam kelompok yang saling menguntungkan, baik yang kecil maupun besar.

Dalam penerapan pada materi pendidikan social ini keteladanan orang tua sangat dibutuhkan, mengingat apa yang dilakukan oleh orang tua dalam kaitannya dengan kehidupan social ini akan berpengaruh pada anak di masa yang akan dating. ${ }^{31}$ Sebagai contoh, setiap jiwa anak yang normal akan terharu mendengar dan menghayati betapa besar jasa seorang ibudalam merawat dan mendidik anak semenjak dalam kandungan. Berangkat dari pendidikan nilai social intern yang diwajibkan bagi anak untuk berbakti kepada orang tua dengan disertai alas an logis dari jasa

\footnotetext{
${ }^{29}$ Abu Ahmadi, Sosiologi Pendidikan, Surabaya: PT. Bina Ilmu, 1982 hal. 43

${ }^{30}$ QS. Al Hujarat: 10

${ }^{31}$ Kamrani Buseri, Pendidikan Keluarga dalam Islam, Yogyakarta: Andi Offset,1990. hal 25
}

FENOMENA, Vol. 20 No. 2 (Juli - Desember 2021) | 263 
besarnya jasa seorang ibu mengandung, melahirkan dan merawat anaknya. Maka keteladanan merupakan pendekatan atau metose mendidik anak utuk beradab kepada orang tua. ${ }^{32}$

Dalam hubungannya dengan masyarakat (social extern), pendidikan social dapat pula melibatkan secara langsunjg kepada anak dalam tidakan nyata atau partisipasi dalam kehidupan bermasyarakat akan mengalami permasalahan pada nak tersebut. Dengan demikian menunutut anak untuk berbaur dengan banyak orang, sehingga anak dapat dibimbing dan diarahkan menuju pribadi yang komunikatif dan peduli terhadap perilaku social sehingga dalam jiwa anak terpatri sikap solidaritas terhadap sesamanya.

Jelaslah disni kiranya anak mengalami perang batin dan menjadi problem anak dalam kehiupan social apalagi dalam hal pembentukan kepribadiannya, dan lebih bahaya lagi apabila masyarakat mengasingkan anak tersebut sehingga dalam kehidupan untuk bersosial anak akan timbul rasa keraguan dan ketidakpercayaan diri terhadap diririnya sendiri, baik dalam kehiupan dalam lingkungan keluarga maupun masyarakat sehari-hari.

\section{SIMPULAN}

Bahwa permasalahan yang terjadi pada keluarga beda agama pada pendidikan anak di desa Wonorejo Kabupaten Situbondo yaitu terkait terkait masalah anak, dimana salah satu suami isteri meminta anak untuk mengikuti Bapaknya namun dari pihak ibunya tidak membolehkan. Pernikahan antar agama bagaimanapun tetap merugikan, terlebih bila dipandang dari sudut paedagogis, sebab secara tidak langsung berarti sudah mempersiapkan lingkungan yang kurang baik bagi kedua belah pihak (pasangan dan kelurganya masing-masing) serta bagi kelangsungan pendidikan anak-anaknya. Anak yang lahir dari pernikahan beda agama ini, pendidikannya diikutkan pada sang bapak (muslim) agar dengan segala daya upaya tdak terseret ke dalam agama ibunya (yang non muslim), mengingat langkah awal menikahi wanita non muslim terkandung semat-mata dakwah islamiyah.

\section{DAFTAR PUSTAKA}

Al Qur'an dan Terjemahannya, Yogyakarta: Universitas Islam Indonesia.

Abu, Ahmadi, Sosiologi Pendidikan, Surabaya: PT. Bina Ilmu, 1982.

Athiyah al Abrasy, Muhammad, Dasar-dasar Pokok Pendidkan Islam, Terjemah oleh H.

Bustani al Ghani dan Djohar Bahary Lis, Jakarta: Bulan Bintang, 1970.

\footnotetext{
32 Ilyas Kaahar, Manajemen Strategis Keluarga Sakinah (Menuju Keluarga Bahagia), Bandung, CV. Mandar Maju, 1992. hal 32
} 
Aulawi, Wasit "Perkawinan antar Agama" dalam Nasehat Perkawinan dan Keluarga (BP4), No. 92, Jakarta: Pustaka Antara, November 1979.

Bumi Aksara Redaksi, Undang-undang tentang Pendidikan Naional (No. 2), Jakarta: Sinar Grafika, 1989.

Buseri, Kamrani, Pendidikan Keluarga dalam Islam, Yogyakarta: Andi Offset,1990.

Depatemen Agama RI, Al Qur'an dan Terjemahannya, Jakarta: PN. Bumi Restu.

Depdikbud RI, Cetakan II, 1989.

Depdikbud, Kamus Besar Bahasa Indonesia, Jakarta: Balai Pustaka,1989.

Dradjat, Zakiah, Membina Nilai-Nilai Moral di Indonesia, Jakarta: Bulan Bintang, 1977.

Dardiri, Ahmadi Hasanuddin, Pernikahan Beda Agama Ditinjau Dari Perspektif Islam Dan Ham. Khazanah, Vol. 6 No.1 Juni 2013

Hasyim, Umar, Anak Sholeh; Cara Mendidik Anak dalam Islam, Surabaya: PT. Bina Ilmu, 1983.

Kaahar, Ilyas, Manajemen Strategis Keluarga Sakinah (Menuju Keluarga Bahagia), Bandung, CV. Mandar Maju, 1992.

Davis, Kingsley, Human Society, New York: Mac-Milan Co., 1963

Marimba, Ahmad D., Pengantar Filsafat Pendidikan Islam, Bandung: PT. al Maarif, 1986.

As Syaukani, Muhammad bin Ali bin Muhammad, t.n., Nailul Athor, Juz VI, Beirut Lebanon: Darul Fikr

Mukhtar, Kamal, Asas-asas Hukum tentang Perkawinan, Jakarta: Bulan Bintang, 1974.

Nasir, Muchtar, et. al., Pedoman Pegawai Pencatat Nikah (PPN), Proyek Pembinaan Sarana Keagamaan Islam, Jakarta: 1982.

Sabiq, Sayyid, Fiqh Islam, Jlled II, Kuwait: daar al Bayan,tt.

Shiddiq, Hasby., al Islam, Juz II, Jakarta: Bulan Bintang, 1956.

Suparlan, Parsudi, Imu Sosial Dasar I, Jakarta: Korkosium antar Bidang Dikbud, 1982.

Suyuth, Jalaluddin Abdurrahman bin Abi Bakar as i, t.n., al Jami'us Shoghir, Juz II, Beirut Lebanon: Darul Fikr.

Tauhied, Abu, Konsepsi Pendidikan seumur hidup dan beberapa factor yang berkaitan dengannya, Yogyakarta: Sumbangsih Offset, 1984 
Perkawinan Beda Agama Dan Dampaknya Terhadap Pendidikan Anak Di Desa.......

Taher, A. Mursal, M., et., Kamus Ilmu JIwa dan Pendidikan, Bandung: PT. al Maarif, 1980.

Undang-undang RI No. 2 Tahun 1989 tentang Sistem Pendidikan Nasional dan Penjelasannya, Semarang: Bulan BIntang.

Zainuddin, Anak Dalam Lingkungan Menurut Pandangan Islam, Semarang: Utama Pria, 1994.

Zein, Muhammad, Metodologi Pengajaran Agama, Yogyakarta:1995.

266 | FENOMENA, Vol. 20 No. 2 (Juli - Desember 2021) 